Bangladesh Journal of Anatomy July 2011, Vol. 9 No. 2 pp 89-92

\title{
Length and Diameter of the Cystic Duct: A Postmortem Study
}

\author{
Nurun Nahar ${ }^{1}$, Shamim Ara², Mushfika Rahman ${ }^{3}$, Halima Afroz ${ }^{4}$
}

\begin{abstract}
Context: The cystic duct connects the neck of the gallbladder to the common hepatic duct to form the bile duct. Sometimes it may be the site of impaction of gallstone. So the length and diameter of cystic duct help the surgeons for proper management.
\end{abstract}

Study design: Descriptive type of study.

Place and period of study: Department of Anatomy, Dhaka Medical College, Dhaka from November 2008 to April 2009.

Materials: 70 postmortem human gallbladders.

Method: The samples were divided into three age groups i.e. group A (10-20 years), Group B (21-40 years), group C (41-60 years) and study of the length and diameter of the cystic duct were carried out.

Result: The mean $\pm S D$ length of the cystic duct ranged from $2.43 \pm 0.90 \mathrm{~cm}$ to $2.91 \pm 0.62 \mathrm{~cm}$ and the mean $\pm S D$ diameter of the cystic duct ranged from $1.47 \pm 0.50 \mathrm{~mm}$ to $2.95 \pm 0.60 \mathrm{~mm}$. Statistically no significant positive correlation was found between age and length of the cystic duct $(p>0.10)$ and there was no statistically significant sex difference $(p>0.50)$ found in between any age group. The difference in mean diameter of the cystic duct in male and in female was statistically significant between group $A \& C(p<0.10)$ and group $B \& C(p<0.10)$. But the difference in mean diameter of the cystic duct between male and female was not statistically significant in any age group $(p>0.10)$.

Conclusion: There was change in diameter of the cystic duct in relation to age.

Key words: Cystic duct, length, diameter.

Introduction:

The cystic duct is about $4 \mathrm{~cm}$ long and connects the neck of the gallbladder to the common hepatic duct to form the bile duct. It is really some what Sshaped and descend for a variable distance in the right free margin of the lesser omentum. ${ }^{1}$ The wall of the neck where it joins with the cystic duct may show a small diverticulae (Hartmann's pouch). This is not a feature of normal gallbladder and is always associated with a pathological condition; it may be the site of impaction of gallstone. ${ }^{2}$

1. Assistant Professor, Department of Anatomy, Ad-din Women's Medical College, Dhaka.

2. Professor and Head, Department of Anatomy, Dhaka Medical College, Dhaka.

3. Assistant Professor, Department of Anatomy, Dr. Sirajul Islam, Medical College, Dhaka.

4. Assistant Professor, Department of Anatomy, Green Life Medical College, Dhaka.

Correspondence: Dr. Nurun Nahar
The mucous membrane of cystic duct resembles that of the gallbladder, but the folds are higher and the diverticulae between them are more extensive. The epithelium of the cystic duct is simple columnar with striated border. The muscularis is poorly developed, but high folds of mucous membrane, collectively called the spiral folds of the cystic duct(Heister's valves) project into the lumen of the duct in the first portion and short or absent in its short end piece. These folds contain smooth muscle. The spiral folds regulate filling and emptying of the gallbladder depending on the pressure in the biliary system ${ }^{3}$.

\section{Materials:}

The samples of human cystic ducts were collected from unclaimed dead bodies that were under examination in the department of Forensic Medicine of Dhaka Medical College, Dhaka from November 
2008 to April 2009. The collected samples were divided into three groups (according to Habiba ${ }^{4}$ ).

Table-I

Age and sex distribution of different groups

\begin{tabular}{lccc}
\hline Group & Age in years & \multicolumn{2}{c}{ No of samples $(n=70)$} \\
\cline { 3 - 4 } & & Male $(n-39)$ & Female $(n-31)$ \\
\hline A & $10-20$ & 3 & 5 \\
B & $21-40$ & 20 & 14 \\
C & $41-60$ & 16 & 12 \\
\hline
\end{tabular}

\section{Methods:}

The $10 \%$ formol saline fixed specimens were initially washed with the free flowing tap water to wash away the formol saline so as to avoid irritation to the eyes and nasal mucosa. It also caused softening of the fixed tissue. Then the specimens were taken in the metallic tray, and the surrounding fat and other unwanted tissues were removed carefully with the help of sharp scissors, fine dissecting forceps and BP blade to expose cystic duct and its related structures.

Parameter studied:

Length of the cystic duct

Diameter of the cystic duct

Procedure for measurement of length of the cystic duct.

The length of the cystic duct was measured by using a silk thread and impose it on a measuring tape and the value was expressed in $\mathrm{cm}$ (Fig.1).

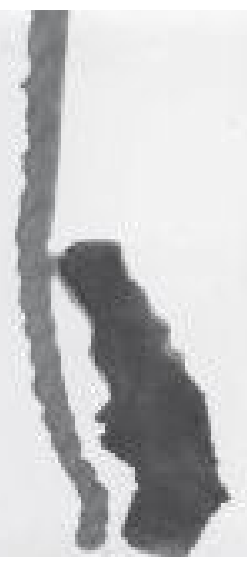

Fig.-1 : Photograph of measurement of length of the cystic duct by using a silk thread

\section{Procedure for measurement of diameter of the cystic duct}

The internal diameter of the cystic duct was measured with the help of a dissecting microscope. At first a 1 centimeter scale was subdivided into 10 equal marks i.e. $1 \mathrm{~mm}$. This print was taken on a transparent plastic sheet and cut into little bit smaller sized pieces then that of a histology slide and placed on that slide. Then the separated cystic duct was cut transversely with scissors as thin as possible, $1 \mathrm{~cm}$ away from the proximal end of the duct. The cut section was placed on a slide i.e. on the cut piece of the inner aspect of the lumen was measured by that scale set on the transparent plastic sheet. Thus the inner luminal diameter was measured and expressed in fraction of $\mathrm{mm}$ (According to Asad $^{5}$ ) (Fig.2,3).

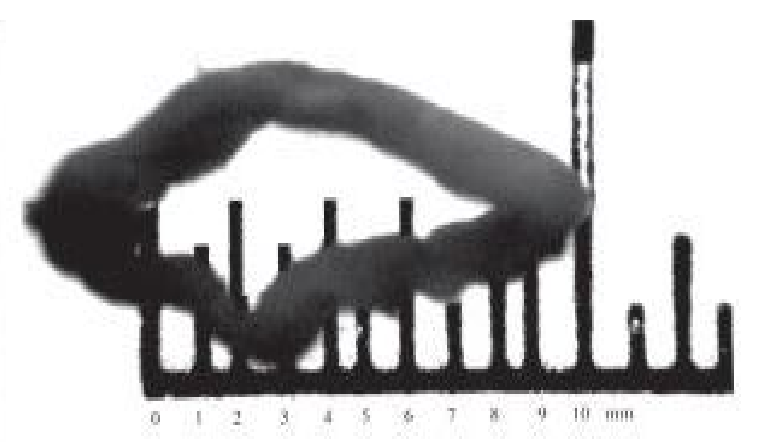

Fig.-2: Photograph of measurement of internal transverse diameter of the cystic duct by using a dissecting microscope.

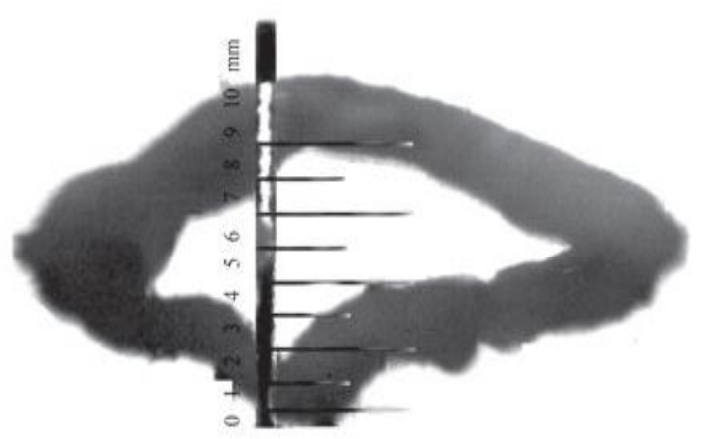

Fig.-3: Photograph of measurement of internal perpendicular diameter of the cystic duct by using a dissecting microscope 


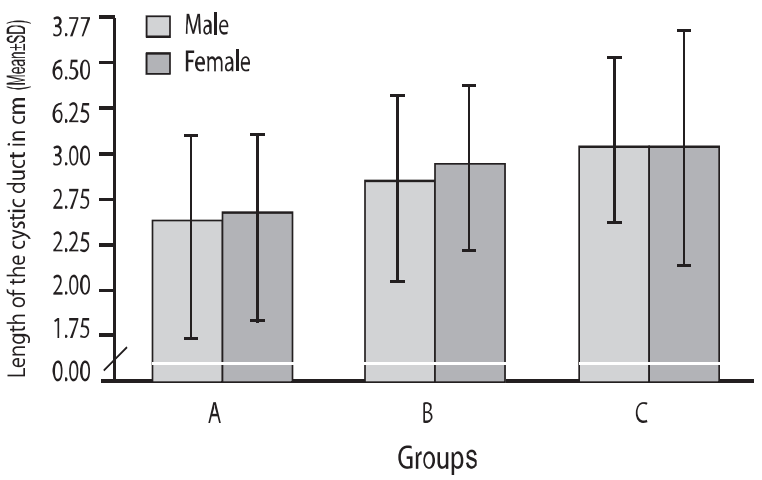

Group A: Age 10-20 years

Group B : Age 21-40 years

Group C : Age 41-60 years

Fig.-4: Length of the cystic duct of male and female gallbladder in different age groups

Result:

In the present study, the mean \pm SD length of the cystic duct was $2.43 \pm 0.90 \mathrm{~cm}$ to $2.91 \pm 0.62$ $\mathrm{cm}$. The difference in mean length of the cystic duct between male and female was not statistically significant at any age group $(p>0.50)$. The difference in mean length of the cystic duct in male was not statistically significant when compared in between any age group $(p>0.10)$. The difference in mean length of the cystic duct in female was not statistically significant when compared in between any age group $(p>0.10)$ (TabII) (Fig.-4). In the present study, the mean \pm SD diameter of the cystic duct was $1.47 \pm 0.50 \mathrm{~mm}$ to $2.95 \pm 0.60 \mathrm{~mm}$. The difference in mean diameter of the cystic duct between male and female was not statistically significant at any age group ( $p>0.01)$. The difference in mean diameter of the cystic duct in male was statistically significant in between group $A \& C$ and group $B \& C$ $(p<0.01)$. The difference in mean diameter of the cystic duct in female was statistically significant in between group $A \& C$ and $B \& C(p<0.01)$ (Tab-III) (Fig.5) .

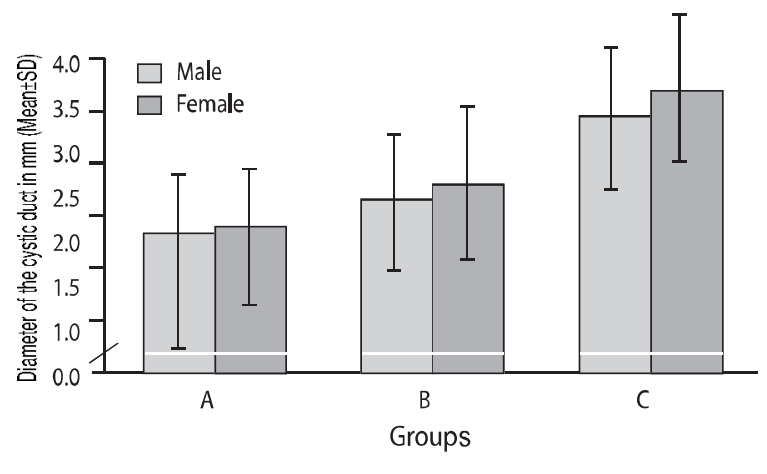

Group A : Age 10-20 years

Group B : Age 21-40 years

Group C : Age 41-60 years

Fig.-5: Diameter of the cystic duct of male and female gallbladder in different age groups

Table II

Length of the cystic duct of male and female gallbladder in different age groups

\begin{tabular}{cccc}
\hline & \multicolumn{2}{c}{ Length (in $\mathrm{cm})$} & \\
Age & Male & Female & $P$ value \\
group & Mean \pm SD & Mean \pm SD & \\
\hline A & $2.43 \pm 0.90$ & $2.48 \pm 0.76$ & $>0.50^{\text {ns }}$ \\
& $(1.40-3.00)$ & $(1.50-3.40)$ & \\
& $n=3$ & $n=5$ & \\
B & $2.68 \pm 0.55$ & $2.80 \pm 0.36$ & $>0.10^{\text {ns }}$ \\
& $(1.20-3.20)$ & $(2.00-3.10)$ & \\
& $n=20$ & $n=14$ & \\
C & $2.91 \pm 0.46$ & $2.91 \pm 0.62$ & $>0.50^{\text {ns }}$ \\
& $(2.00-4.00)$ & $(2.00-4.00)$ & \\
& $n=16$ & $n=12$ & \\
\hline & $P$ value & $P$ value & \\
\hline A vs B & $>0.10^{\text {ns }}$ & $>0.10^{\text {ns }}$ & \\
A vs C & $>0.10^{\text {ns }}$ & $>0.10^{\text {ns }}$ & \\
B vs C & $>0.10^{\text {ns }}$ & $>0.50^{\text {ns }}$ & \\
\hline
\end{tabular}

Figures in parentheses indicate range. Comparison between male and female done by unpaired Student's ' $\mathrm{t}$ ' test and comparison between age group done by One way ANOVA (PostHoc), ns = not significant.

Group A : Age $10-20$ years

Group B : Age 21 - 40 years

Group C : Age $41-60$ years 
Bangladesh J. Anat. 2011; 9(2) : ...

Table III

Diameter of the cystic duct of male and female gallbladder in different age groups

\begin{tabular}{cccc}
\hline \multicolumn{4}{c}{ Diameter (in mm) } \\
\hline Age & Male & Female & $P$ value \\
group & Mean \pm SD & Mean \pm SD & \\
\hline A & $1.47 \pm 0.50$ & $1.70 \pm 0.34$ & $>0.10^{\text {ns }}$ \\
& $(1.00-2.00)$ & $(1.20-2.00)$ & \\
& $n=3$ & $n=5$ & \\
B & $2.07 \pm 0.56$ & $2.20 \pm 0.64$ & $>0.50^{\text {ns }}$ \\
& $(1.00-3.10)$ & $(1.40-3.20)$ & \\
& $n=20$ & $n=14$ & \\
C & $2.73 \pm 0.59$ & $2.95 \pm 0.60$ & $>0.10^{\text {ns }}$ \\
& $(2.00-4.00)$ & $(1.90-3.90)$ & \\
& $n=16$ & $n=12$ & \\
\hline & $P$ value & $P$ value & \\
\hline A vs B & $>0.05^{\text {ns }}$ & $>0.10^{\text {ns }}$ & \\
A vs C & $<0.01^{* *}$ & $<0.001^{* * *}$ & \\
B vs C & $<0.01^{* *}$ & $<0.01^{* *}$ & \\
\hline
\end{tabular}

Figures in parentheses indicate range. Comparison between male and female done by unpaired Student's ' $t$ ' test and comparison between age group done by One way ANOVA (PostHoc), ns = not significant, ${ }^{* * * * * *}=$ significant.

Group A : Age $10-20$ years

Group B : Age 21 - 40 years

Group C : Age $41-60$ years

\section{Discussion:}

In the present study, the mean \pm SD length of the cystic duct was $2.43 \pm 0.90 \mathrm{~cm}$ to $2.91 \pm 0.62 \mathrm{~cm}$. In the present study the length of the cystic duct was lower than that of Borley ${ }^{6}, \mathrm{Khalil}^{7}$, Moore and Dalley ${ }^{8}$ Linthanakhont et $\mathrm{al}^{9}$ found that the length of the cystic duct was $1.42 \mathrm{~cm}$ which was lower than the present finding. In the present study, the mean \pm SD diameter of the cystic duct was $1.47 \pm 0.50 \mathrm{~mm}$ to $2.95 \pm 0.60 \mathrm{~mm}$. According to Sinnatamby ${ }^{2}$ the diameter of the cystic duct is $2-3 \mathrm{~mm}$. This finding is compatible with the findings of group $B$ and group C of the present study. Khalii ${ }^{8}$ found that the diameter of the cystic duct was $1.90 \mathrm{~mm}$. That observation is somewhat similar with the present study.

\section{References:}

1. Snell RS. Clinical anatomy for medical students. $7^{\text {th }}$ ed. Baltimore: Lippincott williams \& Wilkins; 2004. p. 219-2.

2. Sinntamby CS. Last's Anatomy Regional and Applied. 10 $0^{\text {th }}$ ed . Edinburgh: Churchill Livingstone; 1999. p. 257-9.

3. Arey LB. Developmental anatomy : A textbook and laboratory manual of embryology. $7^{\text {th }}$ ed . Philadelphia: W. B. Saunders Company; 1966. p. 260-4.

4. Habiba AC . Roll of preoperative ultrasound measure of gallbladder wall thickness in predicting laparoscopic operablility (M phil. thesis). Dhaka: University of Dhaka ; 2001.

5. Asad MH. Postmortem study of human in Bangladeshi people(M. phil thesis). Dhaka: University of Dhaka ; 2006.

6. Neil R Borley editor. Hepatobiliary system. In; Standring S, Ellis H, Healy GC, Johnson D, WilliamsA, Collins $P$, et al. editors. Gray's anatomy. $39^{\text {th }}$ ed. London: Elsevier Churchill Livingstone; 2005. p. 1227-9.

7. Khalil M. A comperative anatomical study of the extra-hepatic biliary apparatus in goat, cow and man (M phil thesis).Dhaka: University of Dhaka. 1993.

8. Moore KL, Dalley AF. Clinically oriented anatomy. $4^{\text {th }}$ ed. Baltimore: Lippincott Williams \& Willkins; 1990. p. 301-5.

9. Linthanakhont, Khamanarong K, Dhudhisawasdi V. The Anatomical Variations of Cystic Duct in Northeastern Thai Population. The T J Surg, 2005;26(3):73-6. 